\title{
PERILAKU IBU DALAM MELATIH TOILET TRAINING PADA BALITA \\ USIA 12-36 BULAN \\ ( Di BPS Ny. Hj. Siti Munawaroh, SST., Desa Mlati, Kecamatan Mojo, Kabupaten Kediri )
}

Aida Ratna Wijayanti ${ }^{1}$, Sukma Silvianingtyas ${ }^{2}$

${ }^{1,2}$ Akademi Kebidanan Dharma Husada Kediri Jawa Timur

\begin{abstract}
Latihan berkemih (toilet training) pada anak dapat menciptakan hubungan kasih sayang antara ibu dan anak. Latihan berkemih (toilet training) sangat dianjurkan pada balita usia 12 sampai 36 bulan. Tujuan dari penelitian ini adalah untuk mengetahui bagaimana Perilaku Ibu Dalam Melatih Berkemih (Toilet Training) Pada Balita Usia 12 Sampai 36 Bulan Di BPS Ny. Siti Munawaroh, SST Desa Mlati Kecamatan Mojo Kabupaten Kediri.

Rancangan penelitian yang digunakan adalah penelitian deskriptif. Populasi dalam penelitian ini adalah semua ibu yang mempunyai balita usia 12 sampai 36 bulan. Sampel yang digunakan adalah ibu yang memiliki balita usia 12 sampai 36 bulan yang datang waktu penelitian Di BPS Ny. Siti Munawaroh, SST Desa Mlati Kecamatan Mojo Kabupaten Kediri. Teknik sampling menggunakan accidental sampling.Pengumpulan data variabel menggunakan kuesioner. Data dikumpulkan kemudian dilakukan pengolahan dengan proses editing, coding, scoring, tabulating yang selanjutnya dianalisa dengan prosentase.

Dari hasil penelitian pada 20 responden menunjukkan $48,5 \%$ berperilaku baik. 36,5\% berperilaku cukup. $15 \%$ berperilaku kurang dalam melakukan latihan berkemih (toilet training) pada balita.

Berdasarkan analisa dan pembahasan dapat disimpulkan bahwa perilaku ibu dalam melatih toilet training pada balita usia 12-36 bulan dipengaruhi oleh beberapa faktor diantaranya umur, pendidikan, pekerjaan, jumlah anak dan sumber informasi. Untuk itu perlu adanya usaha dari ibu secara pribadi dalam menimbulkan perilaku ibu dalam latihan berkemih (toilet training) serta perlu adanya penyuluhan dari tenaga kesehatan tentang melakukan latihan berkemih (toilet training).
\end{abstract}

\section{Kata kunci : Perilaku, Ibu, BalitaUsia 12-36 bulan, Latihan, Berkemih (toilet training)}

Korespondensi: Jl. Penanggungan 41 A Kota Kediri, Jawa Timur HP: 081233677836 ,email: aidaratna.Bd@gmail.com 


\section{Pendahuluan}

Sebagai Orang Tua tentunya selalu ingin melihat tahap pertumbuhan dan perkembangan buah hatinya. Setiap Orang tua ingin anakanaknya berkembang sesuai usianya dan memiliki kemandirian dalam segala hal nantinya.

Pada anak usia 12 dan 18 bulan kemampuan berbahasanya masih sangat kurang. Anak mulai mengkomunikasikan apa yang dia inginkan. Misalnya dengan menunjuk, mengangkat atau dengan bahasa tubuhnya. Dia juga akan meniru banyak gerak tubuh yang terlihat. Pada usia ini celoteh anak yang tidak jelas bisa berubah menjadi suku kata, misalnya mama papa (Shelov, 2005:243).

Perkembangan bahasa anak masih sangat rendah, merekapun sulit untuk mengungkapkan keinginannya, apalagi ketika anak melakukan aktivitasnya terkadang mereka berkemih tanpa disadari. Hal ini yang mendorong ibu menggunakan popok sekali pakai pada anaknya. Padahal popok sekali pakai tidak baik jika digunakan secara terus menerus dan ibu akan lebih banyak mengeluarkan biaya untuk membeli popok sekali pakai. Oleh karena itu, saat anak berusia 18 bulan sebaiknya orang tua mulai melatih anak dalam kemandirian, salah satunya adalah melakukan toilet training, karena pada usia ini saat yang tepat melatih anak melakukan toilet training.

Seorang minimal harus diajarkan sejak usia 1 tahun. Bila anak diajarkan ketika berusia lebih dari 3 tahun dikhawatirkan akan agak susah mengubah perilaku anak. Selain itu, bila anak sudah lebih dari 3 tahun belum mampu untuk toilet training, boleh jadi ia mengalami kemunduran. Karena pada saat usia 1-3 tahun ia belum mampu melakukan buang air sesuai dengan waktu dan tempat yang telah ditentukan. Akibatnya, anak bisa menjadi bahan cemoohan teman -temannya. (Isticomah, 2010)

Secara umum toilet training dapat dilakukan setiap anak yang sudah mulai memasuki fase kemandirian. Jika anak mulai memahami buang air kecil dan besar, sangat mudah pada anak dalam proses pengontrolan. Anak akan mengetahui kapan saatnya harus buang air besar dan kecil. Kesiapan itulah yang akan menjadikan anak selalu mempunyai kemandirian dalam mengontrol BAB dan BAK (Aziz Alimul, 2005:62).

Menurut WHO usia 3 tahun masih wajar kebiasaan mengompol pada anak di bawah usia 2 tahun merupakan hal yang wajar, bahkan ada beberapa anak yang masih mengompol pada usia 4-5 tahun dan sesekali terjadi pada anak 7 tahun. Anak dibawah usia 2 tahun mengompol karena belum sempurnanya kontrol kandung kemih atau toilet training. Bahkan beberapa ahli menganggap bahwa anak umur enam tahun masih mengompol itu wajar. Walaupun itu hanya dilakukan oleh sekitar $12 \%$ anak umur enam tahun (Isticomah, 2010).

Berdasarkan observasi yang dilakukan oleh Bina Balita Banjarsari Cilacap pada tahun 2011, di dapatkaan data jumlah toddler (1-3 tahun) sebanyak 35 anak. Hasil wawancara dengan 8 ibu yang memiliki anak usia toddler, diketahui sebanyak 6 ibu yang memiliki anak toddler menyatakan merasa kesulitan melakukan toilet training pada anaknya dengan alasan belum mengerti benar cara tepat melakukan toilet training. Sedangkan 2 orang ibu anak usia toddler telah melakukan toilet training di usia anak umur 2,5 tahun, anak sudah sedikit terbiasa dengan BAB atau BAK.(Wikipedia, 2011)

Hasil penelitian di Jawa Timur pada tahun 2011 didapatkan hampir setengahnya $(41,7 \%)$ kurang terlaksana toilet training, hampir setengahnya $(37,5 \%)$ terlaksana dengan cukup toilet training dan sebagian kecil $(20,8 \%)$ melaksanakan toilet trainingsebelum bobok (Dinkes prov jatim, 2012).

Ketrampilan untuk buang air kecil dan buang air besar di toilet memang membutuhkan latihan dan kesiapan balita. Namun sebaiknya orang tua tidak menunda terlalu lama untuk mengajarkan sikecil toilet trining. Jika kita terlambat untuk melatih anak melakukan toilet training dalam usia dua tahun atau lebih besar anak akan terlambat menguasai pengendalian kandung kemih. Akibatnya anak akan lebih sering mengompol di usia sekolah. Anak - anak terlalu lama dibiasakan menggunakan popok sekali pakai pada umumnya juga tidak bisa belajar mengosongkan kandung kemih mereka secara baik sehingga mereka lebih beresiko menderita nyeri saluran kemih, karena kebiasaan menahan BAK (KOMPAS, 10 agustus 2012).

Dari studi pendahuluan yang dilakukan di BPS Ny.Hj. Siti Munawaroh SST, pada tanggal 21 Mei 2013 didapatkan dari $10 \mathrm{ibu}$ balita usia 12 sampai 36 bulan, ada 8 ibu (80\%)yang tidak tahu tentang toilet training dan kebanyakan ibu menganggap dengan menggunakan pampers lebih praktis karena anak bisa BAB dan BAK setiap saat tanpa harus pergi ke kamar mandi. 
Sedangkan $2 \mathrm{ibu}(20 \%)$ diantaranya tahu tentang toilet training serta bagaimana perilaku yang harus diterapkan ibu.

Dengan mempertimbangkan latar belakang di atas, maka penulis tertarik untuk meneliti " Perilaku Ibu Dalam Melatih Toilet Training pada balita usia 12 sampai 36 bulan di BPS Ny.Hj. Siti Munawaroh, SST, Desa Mlati, Kecamatan Mojo, Kabupaten Kediri

Metode

Berdasarkan tujuan penelitian maka peneliti menggunakan desain penelitian deskriptif. Hasil

\section{Karakteristik Responden}

1) Karakteristik Responden Berdasarkan Umur

Tabel 1 Karakteristik responden berdasarkan umur di BPS Ny. Siti Munawaroh Desa Mlati Kecamatan Mojo Kabupaten Kediri

\begin{tabular}{rlcc}
\hline No & \multicolumn{1}{c}{ Umur } & Jumlah (orang) & Prosentase $(\%)$ \\
\hline 1 & $20-25$ tahun & 5 & 25 \\
2 & $26-30$ tahun & 7 & 35 \\
3 & $31-35$ tahun & 4 & 20 \\
4 & $>35$ tahun & 4 & 20 \\
\hline & Jumlah & 20 & 100 \\
\hline
\end{tabular}

Berdasarkan Tabel 1 mayoritas karakteristik responden berdasarkan umur berusia 26-30 tahun sejumlah $35 \%$

2) Karakteristik Responden Berdasarkan Pendidikan

Tabel 2 Karakteristik Responden Berdasarkan Pendidikan di BPS Ny. Siti Munawaroh SST

Desa Mlati Kecamatan Mojo Kabupaten Kediri

\begin{tabular}{llcc}
\hline & \multicolumn{1}{c}{ Pendidikan } & Jumlah (orang) & Prosentase (\%) \\
\hline 1 & Tidak tamat SD & 1 & 5 \\
2 & SD/ Sederajat & 2 & 10 \\
3 & SMP/ Sederajat & 7 & 35 \\
4 & SMA / Sederajat & 6 & 30 \\
5 & Perguruan Tinggi / Akademik & 4 & 20 \\
\hline & Jumlah & 20 & 100 \\
\hline
\end{tabular}

Berdasarkan Tabel 2 mayoritas responden memiliki tingkat pendidikan SMP sebanyak 7 responden $(35 \%)$

3) Karakteristik Responden Berdasarkan Pekerjaan

Tabel 3 Karakteristik responden Berdasarkan Pekerjaan di BPS Ny. Siti Munawaroh SST Desa Mlati Kecamatan Mojo Kabupaten Kediri

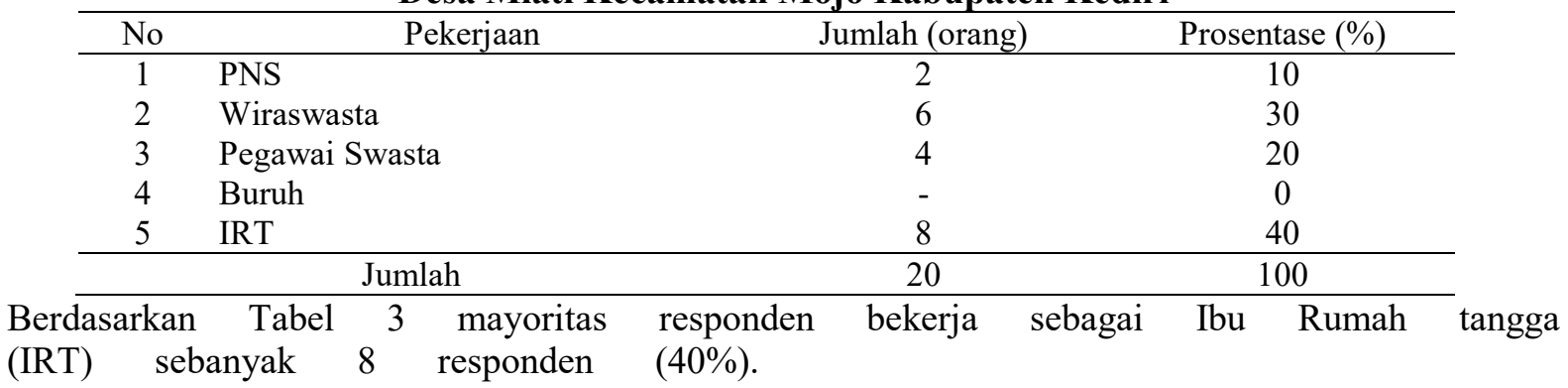

4) Karakteristik Responden Berdasarkan Jumlah Anak

Tabel 4 : Karakteristik responden berdasarkan jumlah anak di BPS Ny. Siti Munawaroh SST Desa Mlati Kecamatan Mojo Kabupaten Kediri 
Aida Ratna Wijayanti:Perilaku Ibu Dalam Melatih Toilet Training Pada Balita Usia 12-36 Bulan (Di BPS Ny. Hj. Siti Munawaroh, SST., Desa Mlati, Kecamatan Mojo, Kabupaten Kediri )

\begin{tabular}{|c|c|c|c|}
\hline No & Jumlah Anak & Jumlah (orang) & Prosentase (\%) \\
\hline 1 & 1 (satu) & 5 & 25 \\
\hline 2 & 2 (dua) & 10 & 50 \\
\hline 3 & 3 (tiga) & 3 & 15 \\
\hline 4 & 4 (empat) atau lebih & 2 & 10 \\
\hline & Jumlah & 20 & 100 \\
\hline
\end{tabular}

Berdasarkan Tabel 4 mayoritas responden memiliki anak berjumlah 2 sebanyak 10 responden (50\%)

5) Karakteristik Responden Berdasarkan Informasi Tentang Toilet Training

Tabel 5 Karakteristik responden berdasarkan informasi tentang Toilet Training di BPS Ny. Siti Munawaroh SST Desa Mlati Kecamatan Mojo Kabupaten Kediri

\begin{tabular}{clccc}
\hline No & & Informasi & Jumlah (orang) & Prosentase (\%) \\
\hline 1 & Pernah & 7 & 35 \\
2 & Tidak Pernah & 13 & 65 \\
\hline & Jumlah & 20 & 100 \\
\hline
\end{tabular}

Berdasarkan tabel 5 mayoritas responden belum mendapatkan informasi mengenai toilet training sebanyak 13 responden $(65 \%)$

6) Perilaku Ibu Dalam Melatih Berkemih (Toilet Training) Pada Balita Usia 12 sampai 36 Bulan

Tabel 6 Distribusi frekuensi Perilaku Ibu Dalam Melatih Toilet Training Pada Balita Usia 12 Sampai 36 Bulan di BPS Ny. Siti Munawaroh SST Desa Mlati Kecamatan Mojo Kabupaten Kediri

\begin{tabular}{cccc}
\hline No & Perilaku Ibu & Frekuensi & Prosentase \\
\hline 1 & Baik & 9,7 & 48,5 \\
2 & Cukup & 7,3 & 36,5 \\
3 & Kurang & 3 & 15 \\
\hline & Jumlah & 20 & 100 \\
\hline
\end{tabular}

Berdasarkan tabel 6 perilaku ibu dalam melatih toilet training pada balita usia 12 sampai 36 bulan adalah prosentase tertinggi yaitu dengan kriteria baik sebanyak 9,7 responden (48,5\%)

7) Perilaku Ibu Dalam Melatih Toilet Training Pada Balita Usia 12 sampai 36 Bulan Dalam Ranah Cognitif

Tabel 7 Distribusi frekuensi Perilaku Ibu Dalam Melatih Toilet TrainingPada Balita Usia 12 Sampai 36 Bulan Dalam Ranah Cognitif di BPS Ny. Siti Munawaroh SST Desa Mlati Kecamatan Mojo Kabupaten Kediri

\begin{tabular}{cccc}
\hline No & Perilaku dalam ranah Cognitif & Frekuensi & Prosentase \\
\hline 1 & Baik & 13 & 65 \\
2 & Cukup & 7 & 35 \\
3 & Kurang & 0 & 0 \\
\hline & Jumlah & 20 & 100
\end{tabular}

Berdasarkan tabel 7 Perilaku ibu dalam melatih berkemih (Toilet Training) pada ranah Cognitif didapatkan hasil frekuensi tertinggi yaitu dengan kriteria perilaku baik sebanyak 13 responden (65\%)

8) Perilaku Ibu Dalam Melatih Berkemih (Toilet Training) Pada Balita Usia 12 sampai 36 Bulan dalam Ranah Affective

Tabel 8 : Distribusi frekuensi Perilaku Ibu Dalam Melatih Toilet Training Pada Balita Usia 12 Sampai 36 Bulan Dalam Ranah Affectif di BPS Ny. Siti Munawaroh SST Desa Mlati Kecamatan Mojo Kabupaten Kediri

\begin{tabular}{cccc}
\hline No & Perilaku Dalam Ranah Affektif & Frekuensi & Prosentase \\
\hline 1 & Baik & 12 & 60 \\
2 & Cukup & 6 & 30 \\
3 & Kurang & 2 & 10 \\
\hline & Jumlah & 20 & 100 \\
\hline
\end{tabular}

Berdasarkan Tabel 8 perilaku ibu dalam melatih toilet trainingdalam ranah affectivedidapatkan hasil frekuensi tertinggi yaitu dengan kriteria perilaku baik sebanyak 12 responden $(60 \%)$ 
9) Perilaku Ibu Dalam Melatih Berkemih (Toilet Training) Pada Balita Usia 12 sampai 36 Bulan Dalam Ranah Psychomotor

Tabel 9 : Distribusi frekuensi Perilaku Ibu Dalam Melatih Toilet Training Pada Balita Usia 12 Sampai 36 Bulan Dalam Ranah Psychomotor di BPS Ny. Siti Munawaroh SST Desa Mlati Kecamatan Mojo Kabupaten Kediri

\begin{tabular}{cccc}
\hline No & Perilaku Dalam Ranah Psychomotor & Frekuensi & Prosentase \\
\hline 1 & Baik & 4 & 20 \\
2 & Cukup & 9 & 45 \\
3 & Kurang & 7 & 35 \\
\hline & Jumlah & 20 & 100
\end{tabular}

Berdasarkan Tabel 9 perilaku ibu dalam melatih Toilet training pada balita usia 12 sampai 36 bulan dalam ranah psychomotordidapatkan hasil frekuensi tertinggi yaitu dengan kriteria perilaku baik sebanyak 13 responden $(65 \%)$

\section{Diskusi}

1. Perilaku Ibu Dalam Melatih Toilet Training Pada Balita Usia 12 Sampai 36 Bulan

Berdasarkan hasil penelitian yang dilakukan didapat 20 responden tertinggi yaitu dengan kriteria baik sebanyak 9,7 responden (48,5\%)

Perilaku merupakan refleksi dari berbagai gejala kejiwaan, seperti pengetahuan, keinginan, kehendak, minat, motivasi, persepsi, sikap dan sebagainya. Secara garis besar perilaku manusia ditentukan dari 3 aspek, yakni fisik, psikis, sosial, namun demikian faktor penentu atau determinan perilaku manusia sulit untuk dibatasi karena perilaku merupakan resultan dari berbagai faktor, baik internal maupun eksternal (lingkungan). Dari segi biologis perilaku merupakan suatu kegiatan atau aktifitas organisme yang bersangkutan baik manusia, hewan maupun tumbuhan (Hikmawati, 2011:99). Menurut Benyamin Bloom (1908) seperti yang dikutip Notoatmojo (2003) dalam Maulana (2012: 194), perilaku manusia dapat dibagi menjadi tiga domain, yaitu Cognitive Domain ( Ranah Kognitif), Affective Domain ( Ranah Efektif),Psichomotor Domain ( Ranah Psikomotor)

Terbentuknya perilaku baru, khususnya pada orang dewasa dapat dilakukan dengan diawali dari cognitive domain,Affectife domain, dan berakhir pada psychomotor domain. Ketiga faktor ini sangat berkaitan sehingga dalam melakukan suatu perilaku ibu perlu memperhatikan ketiga aspek tersebut.

Dari 20 responden (100\%) setuju bahwa toilet training (latihan berkemih) dan BAB pada anak merupakan usaha untuk melatih anak agar mampu mengontrol dalam melakukian buang air besar dan buang air kecil.

Toilet training pada anak merupakan suatu usaha untuk melatih anak agar mampu mengontrol dalam melakukan buang air kecil dan buang air besar (Aziz Alimul, 2005:62).

Sejak anak berumur 12 sampai 36 bulan sebaiknya orang tua mulai melatih anaknya untuk melakukan latihan berkemih (toilet training). Pada saat inilah waktu yang tepat untuk mengajarkan anak untuk melakukan latihan berkemih (toilet training). Jika kita melatih anak terlalu dini kita akan lebih kesusahan dalam melatih berkemih (toilet training), tetapi jika kita terlalu lama melatih anak melakukan berkemih (toilet training) terlalu lama juga tidak akan baik untuk anak.

Berdasarkan penelitian yang dilakukan di BPS Ny. Siti Munawaroh 20 responden (100\%) setuju bahwa latihan berkemih dapat dilakukan dengan teknik lisan dan teknik modeling. Sedangkan 13 responden (65\%) menyatakan bahwa latihan berkemih dapat berlangsung pada fase kehidupan anak yaitu umur 18 sampai 2 tahun.

Dalam melakukan latihan buang air kecil dan besar pada anak membutuhkan persiapan baik secara fisik, psikologis maupun secara intelektual, melalui persiapan tersebut diharapkan anak mampu mengontrol buang air kecil dan besar sendiri (Aziz Alimul, 2005:62).

Dalam melatih anak untuk melakukan toilet training diharapkan anak mempunyai kemampuan sendiri dalam melaksanakan buang air kecil dan buang air besar tanpa merasakan ketakutan ataupun kecemasan sehingga anak akan mengalami pertumbuhan dan perkembangan sesuai usia tumbuh kembang anak. Banyak cara yang bisa dilakukan para orang tua untuk melatih anaknya dalam melakukan toilet training 
2) Perilaku Ibu dalam Melatih (ASUH) Anaknya Untuk Melakukan Toilet Training

Berdasarkan hasil penelitian yang dilakukan pada ranah cognitive didapatdari 20 responden tertinggi adalah dalam kategori baik sejumlah 13 responden $(65 \%)$

Pengetahuan merupakan hasil dari "tahu", dan ini terjadi setelah orang melakukan penginderaan terhadap suatu objek tertentu, sebagian besar pengetahuan manusia diperoleh melalui mata dan telinga. Pengetahuan atau cognitive merupakan domain yang sangat penting dalam pembentukan tindakan seseorang over (over behavior) (Notoatmojo, 2007:146)

Pengetahuan pada seseorang dapat diperoleh melalui berbagai objek. Misalnya setelah orang tersebut melihat atau mendengar suatu objek (informasi / berita) jika orang tersebut tertarik orang tersebut akan mulai terpengaruh atau memiliki keinginan untuk melakukan tindakan yang telah dilihat atau didengarnya. Pengetahuan pada diri seseorang tidak dapat muncul dengan sendirinya, banyak hal yang dapat dilakukan untuk menambah pengetahuan.

Faktor yang mempengaruhi pengetahuan salah satunya adalah faktor umur. Sebagian besar umur responden di BPS Ny Siti Munawaroh SST Desa Mlati Kecamatan Mojo Kabupaten Kediri adalah usia 26 sampai 30 tahun yaitu sebanyak 7 responden $(35 \%)$ umur ini termasuk umur reproduksi dimana tingkat penerimaan informasi dan fungsi pengingatan responden masih baik.

Dari 20 responden $(100 \%)$ menyatakan bahwa (toilet training) latihan berkemih pada anak merupakan suatu usaha untuk melatih anak agar mampu mengontrol dalam melakukan buang air kecil dan buang air besar.

Informasi merupakan fungsi yang sangat penting untuk membantu mengurangi masalah. Informasi menjadi perkembangan yang sangat cepat sehingga orang mengatakan bahwa adanya perkembangan pengetahuan akibat perkembangan ilmu dan penelitian ilmiah (Nursalam, 2003:23)

Menurut Azwar (2009: 34) dalam penyampain informasi media massa membawa pesan - pesan yang berisi sugesti yang dapat mengarahkan opini seseorang. Adanya informasi baru mengenai sesuatu hal tersebut.

Informasi pada ibu memiliki peran besar dalam menimbulkan perilaku baik pada ibu. Jika ibu tersebut aktif dalam bersosialisasi dengan mudah ibu akan mendapatkan informasi dari berbagai tempat dan sarana.
Dari 20 responden menyatakan bahwa tidak pernah mendapatkan informasi tentang toilet training sebanyak 13 responden (65\%), sedangkan sebanyak 7 responden $(35 \%)$ menyatakan bahwa mereka sudah pernah mendapatkan informasi tentang toilet training dari berbagai sudut.

Menurut Nursalam dan Siti Pariani (2001: 132) yaitu makin tinggi tingkat pendidikan seseorang maka semakin luas wawasan dan pengetahuannya sehingga semakin mudah bagi ibu untuk menerima informasi yang bermanfaat bagi ibu sendiri dan juga orang sekitarnya. Selain umur dan pendidikan pekerjaan juga mempengaruhi pengetahuan. Pekerjaan bukanlah sumber kesenangan, tetapi lebih banyak merupakan cara mencari nafkah yang membosankan, berulang dan banyak tantangan (Errich, 1996). Makin banyak bekerja semakin banyak pengalaman yang dimiliki (Hidayat, 2003: 119).

Berdasarkan penelitian dari 20 responden $(100 \%)$ menyatakan bahwa latihan berkemih secara umum dapat dilakukan pada setiap anak yang sudah mulai memasuki fase kemandirian pada anak.

Pengalaman merupakan sumber pengetahuan. Jika responden memiliki anak lebih dari satu, pengalaman mereka akan lebih baik dari pada dengan responden yang baru memiliki anak satu. Responden yang sudah memiliki anak lebih dari satu kemungkinan besar sudah mampu menangani bagaimana jika anak mengompol. Dari pernyataan responden, mereka lebih memilih menggunakan popok sekali pakai (pampers) dengan alasan popok sekali pakai sangat praktis, mereka tidak perlu mencuci popok, tidak perlu mengganti popok setiap anak buang air besar maupun buang air kecil, mereka hanya mengganti jika dirasa popok sudah penuh saja. Padahal jika hal ini dibiarkan secara terus menerus sangat tidak baik bagi anak, utamanya akan timbul ruam popok (diaperush). Lebih baik ibu mulai melatih balitanya untuk melakukan latihan berkemih (toilet training) sejak balita mulai berusia 12 sampai 36 bulan.

\section{3) Perilaku Ibu Dalam Kebutuhan Emosi Dan Kasih Sayang (ASIH) Anak Dalam Hal Kemandirian}

Berdasarkan hasil penelitian yang dilakukan dalam ranah affective didapat dari 20 responden 
tertinggi adalah dalam kategori baik dengan 12 responden $(60 \%)$.

Sikap (attitude) merupakan reaksi atau respon yang masih tertutup dari seseorang terhadap suatu stimulus atau objek. Sikap secara nyata menunjukkan konotasi adanya kesesuaian reaksi terhadap stimulus tertentu. Sikap belum merupakan suatu tindakan atau aktivitas, akan tetapi adalah merupakan "Pre-disposisi" tindakan atau perilaku. Sikap merupakan reaksi terhadap objek terhadap lingkungan tertentu terhadap suatu penghayatan terhadap objek (Notoatmojo, 2007:146)

Sikap ibu dalam hal ini adalah bagaimana ibu menerima respon yang telah diterima. Ibu belum mulai mengaplikasikan stimulus tersebut, akan tetapi perilaku dan tindakan pada ibu akan mulai muncul pada diri ibu. Ibu harus bersikap lebih baik untuk memulai latihan berkemih (toilet training), agar latihan berkemih (toilet training) berhasil. Sikap ibu dalam memberikan kasih sayang juga sangat mempengaruhi terhadap kemauan anak untuk mau diajari latihan berkemih (toilet training)

Dari 20 responden pernyataan tertinggi yaitu terdapat umur 26 sampai 30 tahun sebanyak 7 responden $(35 \%)$. Berdasarkan hasil penelitian yang dilakukan didaptakan hasil 20 responden (100\%) menyatakan bahwa anak mampu duduk dan berdiri sehingga memudahkan anak untuk dilatih buang air besar dan buang air kecil.

Menurut Sunaryo (2004: 199) sikap dikaitkan dengan alasan praktis atau manfaat, dan menggambarkan keadaan, keinginan,. Untuk mencapai tujuan, diperlukan sarana yang disebut sikap. Apabila objek sikap dapat membantu individu mencapai tujuan, individu akan bersikap positif terhadap objek sikap tersebut atau sebaliknya.

Kebutuhan ini berdasarkan adanya pemberian kasih sayang pada anak atau memperbaiki psikologi anak. Perkembangan anak dalam kehidupan banyak ditentukan perkembangan psikologis yang termasuk didalamnya adanya perasaan kasih sayang atas hubungan anak dengan orang tua atau orang disekelilingnya karena akan memperbaiki perkembangan psikologisnya. Terpenuhinya kebutuhan ini akan meningkatkan kasih sayang yang erat (bonding) dan tepatnya basic trust (rasa percaya yang kuat) (Hidayat, 2005:11 - 12).

Kasih sayang seorang ibu pada anaknya sangat diperlukan untuk meningkatkan perkembangan psikologis anak. Perasaan kasih sayang pada anak akan menimbulkan suatu ikatan yang sangat erat, sehingga anak akan lebih percaya jika dilakukan latihan toilet training.Persiapan psikologis dapat berupa gambaran pada anak ketika anak akan melakukan buang air besar maupun buang air kecil, seperti anak tidak rewel ketika akan buang air besar maupun buang air kecil, anak tidak menangis sewaktu buang air besar dan buang air kecil, ekspresi wajah pada anak menunjukkan kegembiraan dan ingin melakukan dengan sendiri. Dengan demikian anak akan lebih mudah melakukan toilet training serta kemungkinan besar tujuan yang diharapkan akan tercapai.

Berdasarkan tabulasi lampiran 18 didapatkan bahwa 20 responden $(100 \%)$ menyatakan bahwa sangat setuju tentang adanya latihan berkemih karena sangat membantu balita untuk berkemih.

Pekerjaan adalah kebutuhan yang harus dilakukan terutama untuk menunjang kehidupannya dan kehidupan keluarga. Bekerja bagi ibu-ibu akan mempunyai pengaruh terhadap kehidupan keluarga(Wawan, $2010: 16$ ).

Oleh karena itu supaya pekerjaan seorang ibu tidak menjadi masalah dalam melakukan latihan berkemih (toilet training) maka seorang ibu harus mempersiapkan maka seorang ibu harus mempersiapkan diri untuk memulai melatih anaknya dalam melakukan latihan berkemih (toilet training). Tuntutan ekonomi yang semakin meningkat juga menjadi penyebab ibu lebih memilih pekerjaanya dri pada harus berada dirumah

\section{4) Perilaku Ibu Dalam Kebutuhan Stimulus Mental (ASAH) Anak Dalam Hal Perkembangan}

Berdasarkan hasil penelitian yang dilakukan dalam ranah psychomotor didapat responden tertinggi adalah dalam kategori cukup dengan 9 responden ( $45 \%)$

Praktek atau tindakan adalah setelah seseorang mengetahui stimulus atau objek kesehatan, kemudian mengadakan penilaian atau pendapat terhadap apa yang diketahui, proses selanjutnya diharapkan ia akan melaksanakan atau mempraktekkan apa yang diketahui atau disikapi (dinilai baik) (Notoatmodjo, 2007: 146)

Setelah ibu mengetahui atau berpendapat ibu dapat menerapkan perilaku tersebut dalam kehidupan sehari - hari. Tentu saja dalam melakukan perilaku tersebut terdapat faktor faktor yang mempengaruhi pelaksanaan perilaku. Faktor yang mempengaruhi perilaku tersebut 
adalah faktor umur, pendidikan, pekerjaan, jumlah anak dan informasi yang didapatkan ibu.

Kebutuhan pada psychomotor ini juga merupakan kebutuhan yang harus dipenuhi untuk mencapai pertumbuhan dan perkembangan secara optimal dan sesuai dengan usia tumbuh kembang pada anak. Pemenuhan kebutuhan asah (stimulasi mental) akan memperbaiki perkembangan anak sejak dini sehingga perkembangan psikososial, kecerdasan, kemandirian dan kreativitas pada anak sesuai dengan harapan atau usia pertumbuhan dan perkembangan (Hidayat, 2005 12).

Stimulus mental pada anak harus terpenuhi sejak dini. Ibu perlu membimbing dan mengawasi perkembangan pada anak sehingga perkembangan pada anak sedikit demi sedikit mulai terbentuk. Dengan demikian jika pemenuhan stimulus mental pada anak sudah mulai terbentuk, akan mempermudah pelatihan

\section{Simpulan}

Secara keseluruhan Perilaku ibu dalam melatih toilet training pada balita usia 12 sampai 36 tergolong baik. Responden memiliki perilaku ASUH, ASAH yang baik, sedangkan untuk perilaku ASIH dalam toilet training tergolong cukup.

\section{DAFTAR PUSTAKA}

Ali, Zaidin. 2010. Dasar - Dasar Pendidikan Kesehatan Masyarakat Dan Promosi Kesehatan. Jakarta: Trans Info Medika

Arikunto, Suharsini. 2006. Prosedur Penelitian Suatu Pendekatan Praktek. Jakarta : Rineka Cipta

Aziz Alimul, Hidayat. 2007. Metode Penelitian Dan Teknik Analisis Data. Jakarta : Salemba Medika

2010. Pengantar Ilmu Keperawatan Anak. Jakarta: Salemba Medika

Ginanjar, Adriana. 2008. Menjadi Orang Tua Istimewa. Jakarta : Arcan

Hikmawati, Isna. 2011. Promosi Kesehatan Untuk Kebidanan. Yogyakarta: Nuha Medika

Kamus Besar Bahasa Indonesia. 2008. Kamus Besar Bahasa Indonesia. Jakarta : Gramedia toilet training pada anak dan kemungkinan tujuan dapat tercapai.

Dari segala pengetahuan yang dimilikinya, seorang ibu dapat mengetahui langkah apa yang akan dilakukan pada saat ia akan melakukan latihan berkemih (toilet training). Seseorang yang memiliki pengetahuan luas biasanya juga memiliki rasa ingin tahu yang tinggi. Rasa ingin tahu berlebih juga dapat membantu ibu dalam mengembangkan semua pengetahuan yang ia punya.

Oleh sebab itu tenaga kesehatan harus banyak memberikan informasi dan bisa mengadakan penyuluhan tentang bagaimana perilaku ibu dalam melatih berkemih (toilet training). Dengan memberikan penyuluhan sedini mungkin, diharapkan mampu menciptakan kebiasaan menyusui pada bayinya meskipun ibu tidak dapat melakukan langsung setiap hari.

\author{
Notoatmodjo,S.2003.Metodelogi Penelitian \\ Kesehatan. Jakarta: Rineka cipta \\ 2005.Metodelogi Penelitian \\ Kesehatan. Jakarta: Rineka cipta \\ 2007.Pendidikan Dan Perilaku \\ Kesehatan. Jakarta: Rineka cipta
}

Nursalam. 2003. Konsep Dan Penerapan Metodelogi Penelitian Ilmu Keperawatan. Jakarta: Salemba Medika

. 2011. Konsep Dan Penerapan Metodelogi Penelitian Ilmu Keperawatan. Jakarta: Salemba Medika

Shelov, Steven. 2004.Perawatan Untuk Bayi Dan Balita. Jakarta: Arcan

Sunaryo. 2004. Psikologi Untuk Keperawatan. Jakarta : EGC

Suhartini, Yupi. 2004. Konsep Dasar Keperawatan Anak. Jakarta: EGC

Wawan, A \& Dewi. 2010. Teori Pengukuran Sikap Dan Perilaku Manusia. Yogyakarta: Nuha Medika

Armawati, Ni Made. 2006.Perubahan Sikap Ibu Tentang Toilet Training Anak Usia 1-3 
tahun. Jember. Available from http://www.google.co.id+dinkes+prov+jatim $+2006+$ tentang+toilet training

Kus Anna, Lusia. 2012. Dini Ajarkan Anak Toilet Training. Kompas

Isticomah. 2010. Jurnal kesehatan. Yogyakarta.

Available from http://www.Skriptistikes.wordpress.com 